\title{
Pharmaceutico-Analytical study of Shadbindu taila
}

\author{
Research Article
}

\section{Sreekala A P1, Anup B Thakar ${ }^{2}$, Harisha C R ${ }^{3}$, Shukla V J4}

\author{
1.PhD Scholar, Department of Panchakarma, 2. Director, \\ 3. HOD Pharmacognosy Laboratory, 4. HOD Pharmaceutical Chemistry Laboratory, \\ Institute of Training and Research in Ayurveda, Jamnagar.
}

\begin{abstract}
Introduction: Shadbindu taila is an Ayurvedic herbo-mineral preparation used in a variety of clinical conditions especially in diseases of upper part of body. This taila is described as exceptionally beneficial for improving the strength of hands. Before a human trial it is essential to evaluate the quality and authenticity of the trial drug, Standardization is needed for assuring quality of any drug and it should be started with the identification and authentication of the drug Materials and method: Pharmacognostical evaluation carried out at Pharmacognosy department, ITRA, Jamnagar, pharmaceutical and HPTLC study were done at Pharmaceutical chemistry department, ITRA, Jamnagar. Microbiological evaluation was carried out at department of Microbiology I.T.R.A, Jamnagar. Results: Organoleptic examination: Colour: Greenish Brown, Odour: Aromatic, Taste: Salty, Touch: Viscous, oily. Pharmaceutical evaluation: specific gravity 0.9177, density 0.8753 Refractive Index 1.4860 , Acid Value 4.042, Saponification Value 132.43, Iodine Value 169.33 HPTLC at 254nm (short wave) showed mainly 6 major spot and at $366 \mathrm{~nm}$ (long wave) showed 2 major spots. No organisms isolated in aerobic and fungal culture, in microbiology evaluation. Conclusion: The trial drug is authentic and devoid of any adulteration. All quality control parameters were found to be within the permissible pharmacopeial limits and the stability and shelf life of the trial drug also will be more as per the pharmaceutical parameters.
\end{abstract}

Key Words: Shadbindu taila, Madhyama paka, Standardization of taila, Pharmaceutical study, Sneha sidhi lakshana, Bhringaraja.

\section{Introduction}

Ayurveda is a medical system highly depends on the availability of medicinal plants. This is an era of industrialization, where the scarcity of herbs is increasing day by day. When the demand of herbal medicine is not fulfilled by the available resources, adulterants were added to compensate it, which means the actual drug is being replaced by another drug of different botanical identity and property. This will eventually leads to a compromise in maintaining the proper standard of formulations. Due to these reasons, Standardization is needed for assuring quality of any drug and it should be started with the identification and authentication of the drug. An Ayurvedic formulation must confirm test for identity, potency, purity, safety and efficacy as per WHO guidelines (1), (2). Moreover in a clinical trial, human trial is situated at the end of the sequence, so that the trial drug should be evaluated in every aspect, from the beginning of the collection of raw drug, processing, preparation and after the preparation. Quality assurance of traditional

* Corresponding Author:

Sreekala A P

PhD Scholar,

Department of Panchakarma,

Institute of Training and Research in Ayurveda,

Jamnagar. India.

Email Id: drsreekuty@gmail.com formulations relies upon good manufacturing practices with adequate batch to batch analysis and standardized method of preparation (3). For the analysis of the drug, a lot of sophisticated methods and tools are available now, and different branches of sciences can be utilized for the same.

Shadbindu taila is an Ayurvedic herbo-mineral preparation used in a variety of clinical conditions especially in diseases of upper part of body. This formulation is described in the context of shiroroga of Bhaishajya ratnavali (4). Taila will be teekshna in potency due to the presence of saindhava in a considerable amount and also it contain drugs like Erandamoola. May be because of that, the dose of taila mentioned as only 6 bindu as per classics, hence the name also came as Shadbindu taila. This taila is described as exceptionally beneficial for improving the strength of hands. Before a human trial it is essential to evaluate the authenticity of the trial drug, and quality control parameters should also be assessed. For that purpose physico-chemical parameters, pharmaceutical evaluation and HPTLC were evaluated here.

\section{Materials and Methods}

All the drugs of Shadbindu taila as per API were obtained from Pharmacy, I.T.R.A, Jamnagar(5). Krishna tila taila is used classically for the preparation, which is obtained from the local market, Jamnagar. Goat's milk also purchased from the local market. The drugs were powdered separately, and they were subjected to 
pharmacognostical evaluation at Pharmacognosy laboratory, I.T.R.A., Jamnagar, Gujarat. The taila is prepared at Dept of Rasa shastra \& Bhaishajya Kalpana Laboratory of I.T.R.A, Jamnagar. Once the formulation was ready, it was subjected to Pharmaceutical evaluation and HPTLC at pharmaceutical laboratory, I.T.R.A, Jamnagar. Microbiological evaluation was carried out at department of Microbiology I.T.R.A, Jamnagar.

\section{Preparation of Shadbindu Taila}

Taila Paka Vidhi (traditional method of Taila preparation) assures the enrichment of Sneha dravya with the active principles of the ingredients (6). medicated oil is prepared by protracted boiling of the Sneha Dravya (base oil) with prescribed drava dravya (liquid drug) and Kalka Dravya (drugs used as a fine paste) to dehydration or near dehydration. This process results in the transfer of some therapeutically active principles of the ingredients into the base oil (7). Shadbindu Taila was prepared in Rasa shastra \& Bhaishajya Kalpana Laboratory of ITRA, Jamnagar, using quality raw material as per AFI (8)

The measured quantity of Krishna tila taila was taken in a stainless steel vessel and heated it over mild flame $\left(80^{\circ} \mathrm{C}\right.$ for $\left.5 \mathrm{~min}\right)$ till it got evaporated moisture content, then specified quantity of drava dravya (Bhringraj Swarasa) was added, followed by fresh goat milk and bolus of Kalka were added to it. After thorough mixing of Kalka, the mixture was subjected to heat. Heating was maintained in a temperature between $95-100^{\circ} \mathrm{C}$ and stirring was continued. Heating was continued for 3 day till Sneha Siddhi Lakshanas were obtained (Madyama paka). On 3rd day, after obtaining desired Sneha Siddhi Lakshanas, the vessel was removed from the fire and then specified quantity of saindhava was added as patrapaka. After that oil was filtered through a two folded cotton cloth in its hot stage itself. The prepared oil (after cooling), was stored in a properly labelled air tight container.

\section{Results}

\section{Pharmacognostical Study}

Identification and authentication of herbal drugs is carried out by pharmacognostical study. A routine use of such scientific techniques will lead to standardization of the Ayurvedic product to a certain extent and would definitely help in building confidence in use of these products (9).

Table 1: The drugs of Shadbindu taila

\begin{tabular}{l|l|l|} 
Drug & Scientific name & Part used \\
$\begin{array}{l}\text { Eranda } \\
\text { mula }\end{array}$ & Ricinus communis L & Root \\
\hline Tagara & Valeriana wallichi DC & Root \\
\hline Satahwa & Foeniculum valgare (Mill.) & Fruit \\
\hline Jivanti & $\begin{array}{l}\text { Leptadenia reticulate(Retz) } \\
\text { Wight\& Arn }\end{array}$ & Root \\
\hline Rasna & $\begin{array}{l}\text { Pluchea lanceolata(CB } \\
\text { Clarke) }\end{array}$ & Root \\
\hline Bhringa & Eclipta alba(L) & Whole plant \\
\hline Vidanga & Embelia ribes Brum.F & Fruit
\end{tabular}

\begin{tabular}{|l|l|l|}
\hline Yashti & Glycorrhyza glabra(L) & Root \\
\hline Shunti & Zingiber officinalis Rosc & rhizome \\
\hline $\begin{array}{l}\text { Saindhava } \\
\text { Krishna tila }\end{array}$ & Rock salt & - \\
taila & Sesame oil & - \\
\hline $\begin{array}{l}\text { Aja paya } \\
\text { Bhringaraja } \\
\text { swarasa }\end{array}$ & Goats milk & - \\
\hline
\end{tabular}

There are two steps in raw drug analysis:

\section{Organoleptic Study}

This is the evaluation carried out with sense organs and it is very important for assessing the genuinity of ayurvedic drugs. The raw drugs and its powder were separately evaluated by organoleptic characters like colour, odour, taste and touch. Characteristics of the samples were identified and noted.

\section{Powder microscopy}

Powdered drug was studied microscopically and microscopic characters of individual drugs were noted. The powder of the drug was dissolved with water followed by microscopy of the sample without stain and after staining with Phloroglucinol $+\mathrm{HCl}$. Microphotographs of the sample were also taken under Carl-zeiss trinocular microscope.

\section{Observations}

Every taila will have a characteristic colour and odour, relating to the herb used (10)hence by assessing the features we can find out the true quality of the formulation. Findings of Organoleptic examination of Shadbindu taila are tabulated below:

Table 2: Organoleptic properties

\begin{tabular}{|r|l|l|}
\hline 1 & Colour & Greenish Brown \\
\hline 2 & Odour & Aromatic \\
\hline 3 & Taste & Salty \\
\hline 4 & Touch & Viscous, oily \\
\hline
\end{tabular}

\section{Powder microscopy}

Observations on podwer microscopy were listed below, and the micro photographs were also given

Table 3: Powder Microscopy

\begin{tabular}{|c|c|c|}
\hline $\begin{array}{l}\text { Sl. } \\
\text { No }\end{array}$ & Name of Drug & $\begin{array}{c}\text { Powder microscopy } \\
\text { results }\end{array}$ \\
\hline 1 & Ricinus communis $L$ & $\begin{array}{l}\text { Lignified Fibres } \\
\text { Starch grains } \\
\text { Pitted vessels } \\
\text { Rosette crystals } \\
\text { Group of fibres }\end{array}$ \\
\hline 2 & Valeriana wallichi $D C$ & $\begin{array}{l}\text { Simple fibres } \\
\text { Prismatic crystals } \\
\text { Scleriform vessels } \\
\text { Parenchyma }\end{array}$ \\
\hline 3 & $\begin{array}{l}\text { Foeniculum valgare } \\
\text { (Mill.) }\end{array}$ & $\begin{array}{l}\text { Epicarp cells } \\
\text { Fibres with oil globules } \\
\text { Parenchyma with oil } \\
\text { globules } \\
\text { Oil globules }\end{array}$ \\
\hline
\end{tabular}




\begin{tabular}{l|l|}
4 & Leptadenia \\
reticulata(Retz) Wight\& \\
Arn
\end{tabular}

5 Pluchea lanceolata(C B Clarke)

6 Eclipta alba(L)

7 Embelia ribes Brum.F

9 Zingiber officinalis Rosc

Border pitted vessels

Cork in surface

Lignified fibres

Rosette crystals

Prismatic crystals

Starch with Hilum

Cork cells

Fibres

Rosette crystals

Stone cells

Brown content

Simple Starch grains

Anisocystic stomata

Pollen grains

Oil globules

Fibres

Warty trichome with base

Oil globules

Olioresine content

Scleroids

Trichome

Stone cells

8 Glycorrhyza glabra(L)

Crystal fibres

Fibre with starch grains

Lignified fibres

Pitted vessels

Rhomboidal crystal

Cork cells

Cork in surface

Scalariform vessels

Starch grains

fibres

Micro-photographs of each ingredients

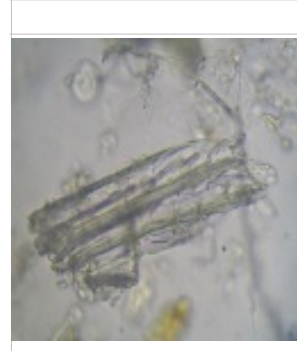

1.1: Group of fibres
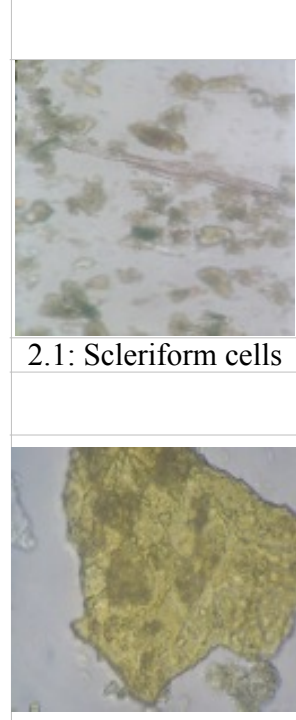

3.1: Epicarp cells
2.1: Scleriform cells

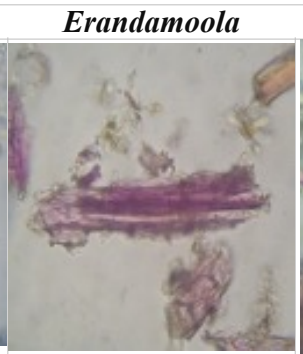

1.2: Lignified fibre

Tagara

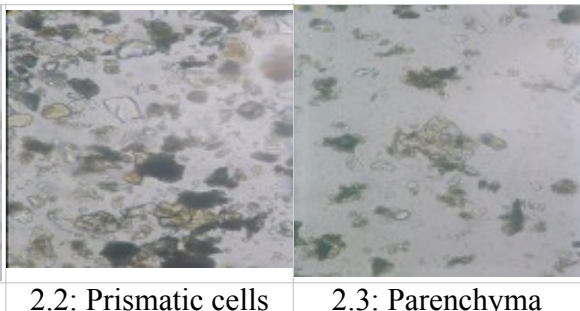

Shatapushpa

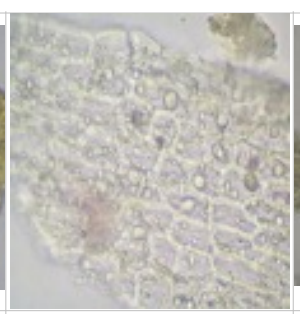

3.2: Parenchyma with oil globules

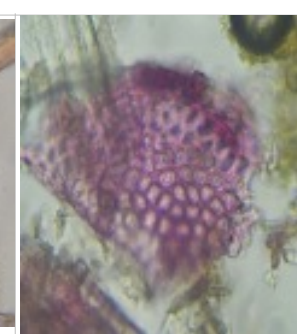

1.3: Pitted vessels

2.3: Parenchyma

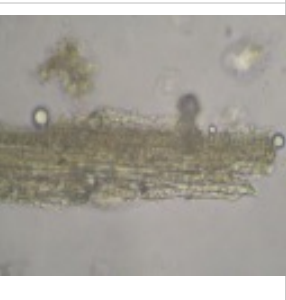

3.3: Fibres with oil globules
Jeevanti

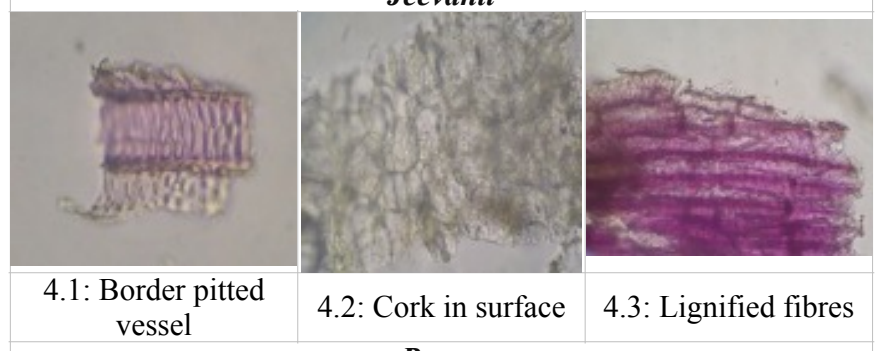

Rasna
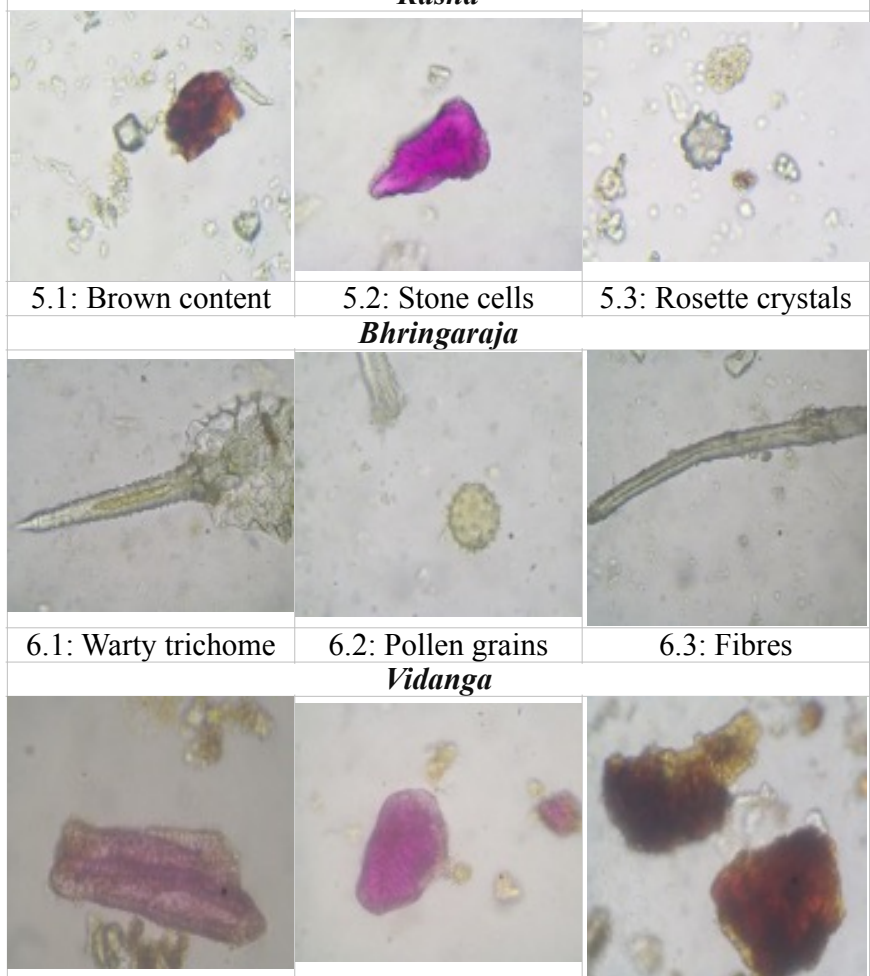

7.1: Scleroids

7.2: Stone cell

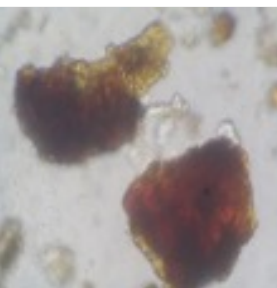

7.3: Oleo-resin content

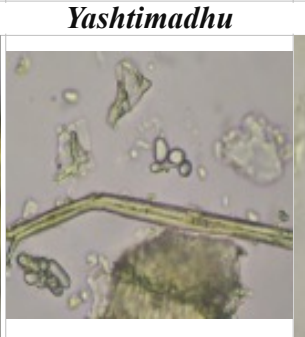

8.2: Fibre with starch grains

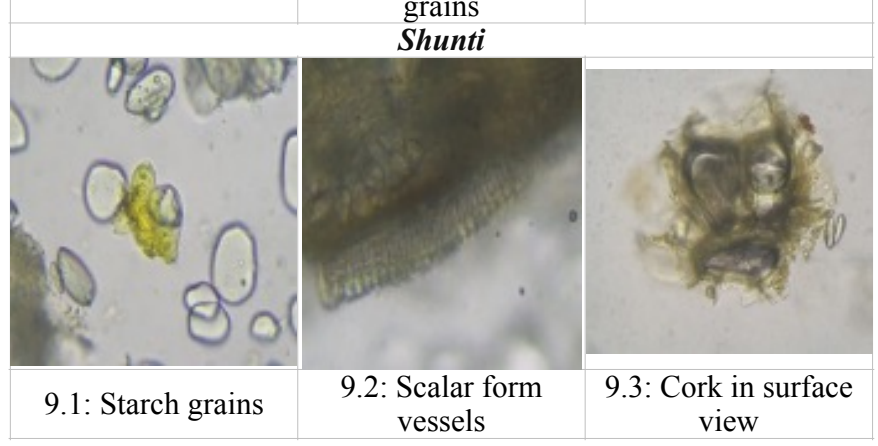

\section{Pharmaceutical evaluation}

Pharmaceutical evaluation is carried out for assuring the quality of the prepared drug, and it helps to calculate the shelf life also. As per API, Specific Gravity, Acid Value, Saponification value, Iodine value and Refractive Index are the parameters to be evaluated 
for the quality assessment of a taila. The specific gravity of a liquid is the weight of a given volume of the liquid at 250 (unless otherwise specified) compared with the weight of an equal volume of water at the same temperature, all weighing being taken in air (11). The refractive index $(\eta)$ of a substance with reference to air, is the ratio of the sine of the angle of incidence to the sine of the angle of refraction of a beam of light passing from air into the substance (12). The saponification value is the number of $\mathrm{mg}$ of potassium hydroxide required to neutralize the fatty acids, resulting from the complete hydrolysis of $1 \mathrm{~g}$ of the oil or fat (13). The Iodine value of a substance is the weight of iodine absorbed by 100 part by weight of the substance (14). The acid value is the number of $\mathrm{mg}$ of potassium hydroxide required to neutralize the free acids in $1 \mathrm{~g}$ of the substance (15). listed below:

The results of physico-chemical evaluation is

Table 4

\begin{tabular}{|l|l|l|}
\hline No. & Parameters/ Sample & Shadbindu taila \\
\hline 2 & Specific Gravity & 0.9177 at room temp \\
\hline 3 & Acid Value & 4.042 \\
\hline 4 & Saponification value & 132.43 \\
\hline 5 & Iodine value & 169.33 \\
\hline 6 & Refractive Index & 1.4860 \\
\hline
\end{tabular}

\section{High Performance Thin Layer Chromatography}

TLC and HPTLC Chromatography is an analytical technique where the technique used is separation of closely related compounds from a mixture. This is an important analytical technique used for the analysis of herbal medicines. A fingerprint of the preparation was obtained by HPTLC for standardization purpose. The fingerprint has the potential to determine authenticity and reliability of chemical constituents of herbal drugs and formulations $(16,17)$.

\section{Steps involved in HPTLC}

a.Selection of chromatographic layer.

b.Sample and standard preparation.

c.Layer pre-washing,

d.Layer pre-conditioning.

e.Application of sample and standard.

f.Chromatographic development.

g.Detection of spots.

h.Scanning.

i.Documentation of chromatic plate

\section{Rf. Value (Retention factor value):}

The distance of each spot from the point of its application was measured and recorded and the Rf. Value was calculated by dividing the distance travelled by the spots by the distance travelled by the front of the mobile phase (18).

\section{Results}

In the photo documentation of Shadbindu taila at $254 \mathrm{~nm}$ (short wave) observed mainly 6 major spot and $\mathrm{Rf}$ values are $0.06,0.2,0.23,0.25,0.3$ and 0.68 .At $366 \mathrm{~nm}$ (long wave) showed only 2 major spots. Rf values are $0.06,0.25$.On densitometric scan at $254 \mathrm{~nm}$, Shadbindu taila showed 6 peaks, peak with Rf value 0.3 contributed major area $34.4 \%$. Densitometric scan at $366 \mathrm{~nm}$ showed 2 peaks in which the peak with $\mathrm{Rf}$ value 0.06 contributed major area $82.05 \%$.

\section{Densitogram of Shadbindu taila}

Image 10: Peak at 254nm

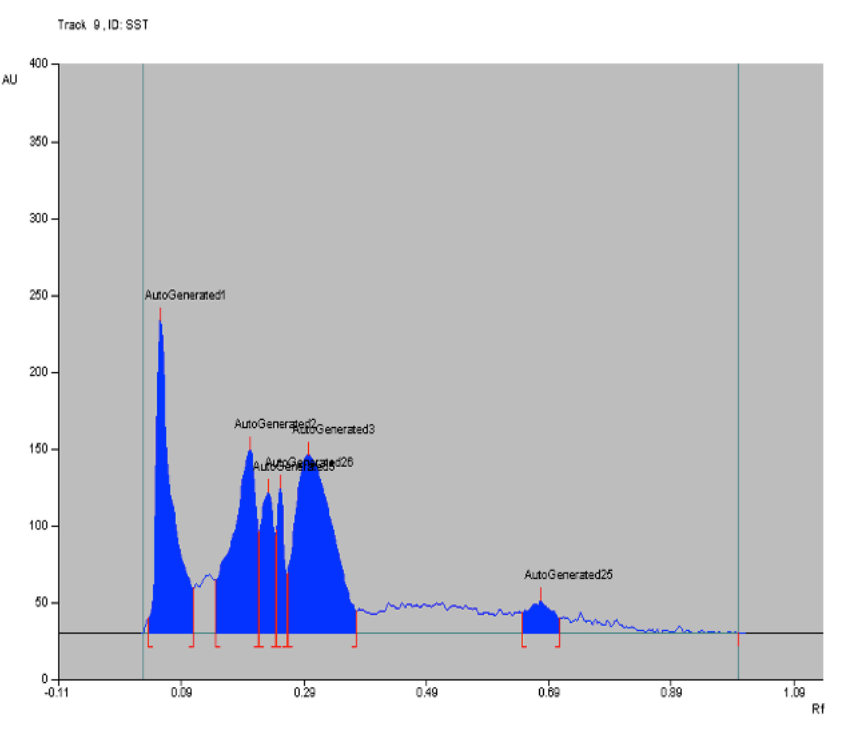

Image 11: Peak at 366nm

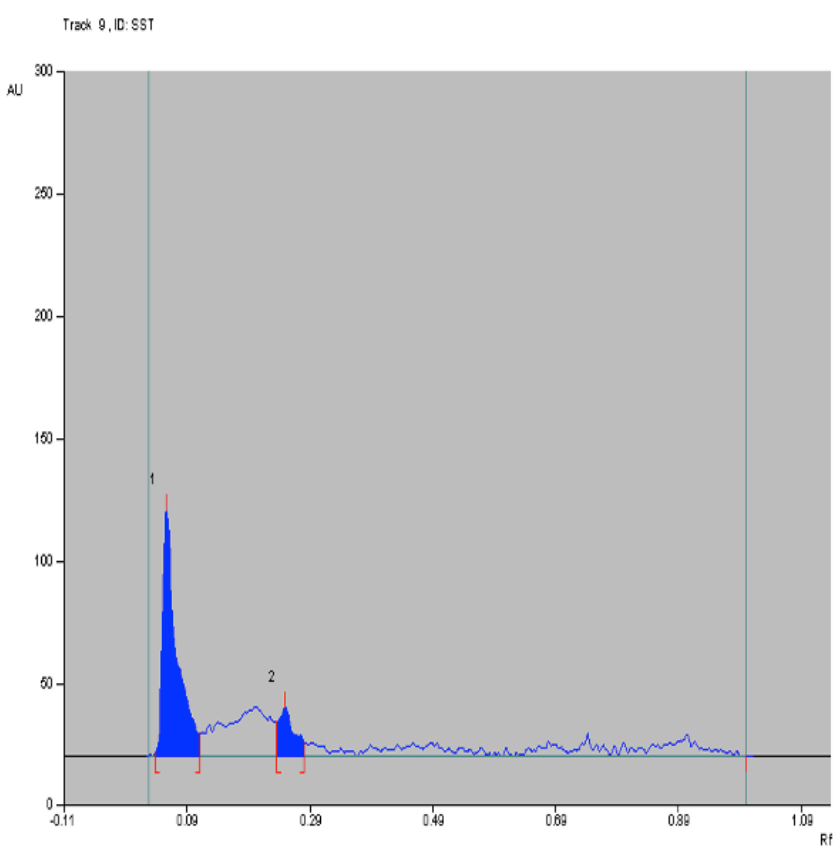

\section{Microbiological Investigation}

Microbial culture examination helps to find out the contamination of prepared drug by microorganisms. This can happen at any stage of preparation, storage, or handling, hence before the administration of medicine to the trial subjects one must ensure that microbial presence in the sample is in the normal limit.

\section{Aerobic culture report}

No organisms isolated (after $48 \mathrm{hrs}$ of incubation at $37 \mathrm{oC}$ ) 


\section{Fungal Culture report}

No fungal pathogen isolated (after 7 days of incubation at $37^{\circ} \mathrm{C}$ )

\section{Discussion}

Quality assurance is an integral part of all systems of medicine to ensure the quality medicament. Standardization is another essential factor for ASU preparations in order to assess their quality based on the concentration of chemical or bioactive marker $(19,20)$. Modern bio-analytical techniques like HPTLC and HPLC are being used to achieve the aforesaid objectives (20).Here the trial drug is evaluated in various ways and the discussions based on that are given below.

As per Acharya Susruta the paka for Nasya is madhyama (21), and as per Acharya Sharngadhara madhyama is considered as a paka suitable for all purposes (22). So here the taila is prepared to madhyama paka so as to extract maximum active chemical constituents (20). Colour of taila depends on the ingredients added to it and the proper paka attained. Here the colour is greenish brown probably due to the greenish appearance of Bhringaraja swarasa. Order is aromatic due to the addition of particular medicinal herbs to the Tila Taila. Powder microscopic examination helps to authenticate the drugs mentioned in the yoga and there by exclude adulteration. Refractive index indicate density of sample compared to air and liquid media; the value for Shadbindu taila was 1.4860. Specific gravity indicates the presence of solute content in the solvent, Specific gravity of plain Tila Taila is 0.90- 0.92. [23], here the value of Shadbindu taila is 0.9177 . Free fatty acids are nascent and hence susceptible for formation of newer compounds in an attempt to get stabilized which has been seen in the form of changes in saponification value after Sneha Paka (19). The amount of alkali needed to saponify a given quantity of oil will depend upon the number of $\mathrm{COH}$ group present in it; the saponification value also indicates the average molecular weight /chain length of all fatty acids present or it is the amount of all free fatty acids present in a sample. Fatty acids with longer chains, have low saponification value, and the shorter chain fatty acids have high saponification value. Shorter chain fatty acids (high saponification value) have faster rate of absorption than longer chain fatty acids; saponification value of ST was found to be 132.43. The acid value indicates the presence of free fatty acids in the oil which are responsible of rancidity of the compounds; higher the free fatty acid the more is the rancidity. This will help to decide the shelf life of the oil; acid value for ST was 4.042. Iodine value indicates the degree of unsaturation of oil; greater the degree of unsaturation, higher will be the possibility of absorption and atmospheric oxidation leading to rancidity. The more the iodine number, the more unsaturated fatty acid bonds are present; unsaturated fatty acid is better absorbed than saturated fatty acids, the value of ST was found to be 169.33 .
The HPTLC of Shadbindu taila, 6 major spots were observed at $254 \mathrm{~nm}$ and 2 major spots were observed at $366 \mathrm{~nm}$ indicating it's possible compounds in the matrix, which may be responsible for therapeutic activity of the same. Microbial culture examination helps to find out the contamination of prepared drug by micro-organisms, here the values were in normal limits.

\section{Conclusion}

By analysing the results it can be concluded that the trial drug is authentic and devoid of any adulteration. All quality control parameters were found to be within the permissible pharmacopeial limits and the shelf life of the trial drug also will be more as per the pharmaceutical parameters. The therapeutic efficacy and safety of the trial drug should be evaluated through the pre-clinical and clinical studies.

\section{References}

1. Soni $\mathrm{P}$ et al. Standardization of Ayurvedic formulation Panchasakar Churna. Journal of Global Pharma Technology. 2010; 2(2): 46-50.

2. Dobriyal RM, Narayana DBA. Ayurvedic Herbal Raw Material. The Eastern Pharmacist, 1998; 31-35.

3. Trivedi PC. 2002. Medicinal Plants - Traditional Knowledge. IK - International Publishing House Pvt. Ltd. New Delhi, India, pp no. 1-10.

4. Kaviraj Govind Das Sen Bhaishajya ratnavali edited by Bhisagratna Shri Brahmasankar Mishra Volume iii 65/81-83 Chaukhamba Sanskrit bhavan 2006 pp 323.

5. Anonymous. The Indian Pharmacopoeia, Government of India, Ministry of Health and Family Welfare. 6th ed., Vol. I. Ghaziabad: The Indian Pharmacopoeia Commission; 2010. p. 201.

6. Shailajan S, Menon SN, Tiwari BR, Singh AS. Standardization of Shadbindu Taila: An Ayurvedic oil based medicine. Аyu. 2013;34(1):103-107. doi:10.4103/0974-8520.115442.

7. Lahorkar P, Ramitha K, Bansal V, Anantha Narayana DB. A comparative evaluation of medicated oils prepared using Ayurvedic and modified processes. Indian J Pharm Sci 2009;71:656-62.

8. Anonymous. The Ayurvedic Formulary of India. Part I, 2nd revised English ed. New Delhi: Government of India, Ministry of Health and Family Welfare, Department of Indian System of Medicine and Homeopathy; 2003. p. 154, 351.

9. Shailajan, Sunita \& Singh, Ashish \& Tiwari, Bhavesh. (2010). Quality control and Standardization of an Ayurvedic Taila formulation. International journal of biomedical research and analysis. 1. 78-81.

10. Lahorkar P, Ramitha K, Bansal V, Anantha Narayana DB. A comparative evaluation of medicated oils prepared using Ayurvedic and modified processes. Indian J Pharm Sci 2009; 71:656-62. 
11. Anonymous, The Ayurvedic Pharmacopoeia of India, 1st ed, Govt. of India: Ministry of Health and Family Welfare; Part II, Vol. I, 2007: Appendix-3(3.1), Pg. 191.

12. Anonymous, The Ayurvedic Pharmacopoeia of India, 1st ed, Govt. of India: Ministry of Health and Family Welfare; Part II, Vol. I, 2007: Appendix-3(3.2), Pg. 190.

13. Anonymous, The Ayurvedic Pharmacopoeia of India, 1st ed, Govt. of India: Ministry of Health and Family Welfare; Part II, Vol. I, 2007: Appendix-3(3.10), Pg. 199.

14. Anonymous, The Ayurvedic Pharmacopoeia of India, 1st ed, Govt. of India: Ministry of Health and Family Welfare; Part II, Vol. I, 2007: Appendix-3(3.11), Pg. 200.

15. Anonymous, The Ayurvedic Pharmacopoeia of India, 1st ed, Govt. of India: Ministry of Health and Family Welfare; Part II, Vol. I, 2007: Appendix-3(3.12), Pg. $201 \mathrm{~T}$.

16. Rajkumar, and B.N.Sinha. Chromatographic finger print analysis of budmunchiamines in Albizia amara by HPTLC technique, Int. J. Res. Pharm. Sci 1(3): 313-316 (2010).(HPTLC FINGERPRINT).

17. Kartik Chandra Patra, Surendra K. Pareta, Ranjit K. Harwansh, K. Jayaram Kumar Traditional approaches towards standardization of herbal medicines-a review, Journal of Pharmaceutical
Science and Technology Vol. 2 (11), 2010,372-379). (HPTLC FINGERPRINT.

18. Anonymous, The Ayurvedic Pharmacopoeia of India, 1st ed, Govt. of India: Ministry of Health and Family Welfare; Part II, Vol. I, 2007: Appendix-2(2.2.13.), Pg.146.

19. Shrestha, Sahara. (2017). Standard Manufacturing Procedure and Quality Control of Karpanpatru Rollon Prepared with Coconut Oil. Journal of Ayurveda Medical Sciences. 2. 10.5530/jams.2017.2.17.

20. Shailajan, Sunita \& Menon, Sasikumar \& Trivedi, Meenakshi \& Tiwari, Bhavesh. (2012). Quality assessment of a traditional oil based Ayurvedic formulation: Yashtimadhuka Taila. Journal of Pharmacy Research. 5. 1112-1115.

21. Susruta, Susruta Samhitha, Nibandha sangraha commentary by Dalhana and Nyaya chandrika panjika of Gayadasa, Chowkhambha Sanskrit sansthan, Varanasi, 2010, 31/11. Pp:509.

22. Sharangdhara, Sharangdhara Samhita, Dipika and Gudartha dipika Hindi Commentary, Edited by Pt Parashuram Shastri Vidyasagar, Krishnadas Academy, Varanasi, Reprint - 2000,9/17,pp 214.

23. Abhishek Singh, Dipali Parekh, Dr. D. B. Vaghela, Pharmacognostical and pharmacuetical study of shadbindu taila: an ayurvedic oil based medicine ,World Journal of Pharmaceutical Research SJIF Impact Factor 8.074 Volume 8, Issue 6, 1031-1040. 